\title{
National identity among economic and non-economic immigrants
}

\author{
Stuart Campbell ${ }^{1}{ }^{1}$
}

Received: 7 June 2018 / Accepted: 25 October 2018 / Published online: 9 November 2018

(c) The Author(s) 2018

\begin{abstract}
Using recent survey data from the UK, I show that immigrants who originally migrated for family reasons or as refugees are more than twice as likely to report a host national identity as those who migrated for economic reasons. A large part of this gap is explained by differences between immigrant groups in national origin and other observed characteristics. However, even after accounting for such differences comprehensively, family immigrants and refugees remain around 13 and 8\% more likely to report a host national identity respectively. These two groups still remain more likely to report a host national identity when restricting the analysis to immigrants without citizenship, to those with only weak incentives to acquire citizenship, or to those from origin countries without linguistic or cultural connections to the UK via the British Commonwealth. I suggest that average differences in time horizons between immigrant groups may be an important unobserved explanatory factor.
\end{abstract}

Keywords Immigration · Assimilation · Identity

JEL codes $\mathrm{D} 71 \cdot \mathrm{Z} 13$

\section{Introduction}

National identity binds together heterogeneous groups of individuals within and across national borders. Governments have actively cultivated unified national identities within their own territories, in the belief that these collective affiliations foster social cohesion (Berry 1974; Uberoi and McLean 2007). The existing empirical evidence on pro-social behaviour and redistributive preferences is broadly

Stuart Campbell

s.campbell@ucl.ac.uk

1 Department of Social Science, UCL Institute of Education, University College London, 55-59 Gordon Square, London WC1H 0NU, UK 
supportive of this belief: people do seem to be more generous and cooperative towards those with whom they share a common identity (Bernhard et al. 2006; Chen and Li 2009; Costa i Font and Cowell 2015). In an age of rising tension over international migration, a key question for policy-makers in immigrant-receiving countries is therefore whether the foreign-born retain the identity of their origin country, or come to adopt the identity of their hosts. Public concern over these matters is high (Kellner 2007; Kiss and Park 2014).

There is a literature in economics which responds to this concern, much of which has been guided by Akerlof and Kranton's (2000) contribution on the economics of identity (Casey and Dustmann 2010; Constant et al. 2009; Constant and Zimmermann 2008; Dustmann 1996; Georgiadis and Manning 2013; Manning and Roy 2010; Masella 2013). One of the key insights driving this work is that adopting a new national identity involves social and psychological costs and benefits. The costs arise from abandoning the previous identity and adapting to new behavioural reference points in the host country, while the benefits are associated with increasing prospects for social integration. As with other country-specific investments, the relative weight of these costs and benefits must partly be determined by the length of time that an immigrant intends to stay in the host country. The expected gains from adopting the host national identity should be greatest for those who intend to stay permanently, but lower for those with uncertain time horizons, and lower still for those who intend to return to the home country after a short period of time.

Time horizons are partially embedded in the original motive for migration. For example, refugees often expect to stay longer than those in other immigrant groups, since safety concerns reduce the possibility of return to the home country. Family immigrants are also likely to envision a longer stay than others on average, since coordinated relocation of partners and children is costly, both on arrival in the host country and for any proposed departure. In contrast, economic and student immigrants often have the option or the explicit intent to return to their home country more quickly. Although we cannot observe these average differences in time horizons directly, existing empirical work does suggest that family immigrants are less prone to out-migration than others (Bijwaard 2010; Home Office 2014), and that patterns of human capital investment and earnings assimilation among refugees are also consistent with a longer intended stay (Borjas 1982; Cortes 2004; Khan 1997).

My innovation is to introduce these implicit differences in time horizons to the analysis of immigrant national identity. Given a longer expected length of stay, refugees and family immigrants have the most to gain from adopting the host national identity, while economic and student immigrants have the least. Although it is well established that time horizons are important for the economic assimilation of immigrants, the question of whether immigrant national identity may also be responsive to the expected length of stay has so far remained unanswered. This is an important omission, since immigrant national identity matters both for the wellbeing of immigrants themselves (Akerlof and Kranton 2000, suggest that the choice of identity may be “...the most important 'economic' decision people make") as well as for the acceptance of immigrants in the host population (Manning and Roy 2010).

I examine how uptake of the host national identity varies between economic, student, family, and refugee immigrants. I use a unique survey measure to distinguish between these groups, and construct a multinational sample of over 76,000 
immigrants in a large and diverse immigrant-receiving country. The data I use come from the UK, but the principle should apply more generally: other things equal, longer time horizons in the host country increase the expected gains from adoption of the host national identity.

Non-economic immigrants are now a substantial proportion of the foreign-born population in many immigrant-receiving countries. Several host countries saw a shift away from economic migration and towards family reunification over the second half of the twentieth century (Ferrie and Hatton 2015). Large exporters of higher education such as the UK and the USA have also seen a rising proportion of immigrants arrive as students and stay on to work after completing their studies (Bratsberg 1995). Moreover, from the early 2010s onwards, several countries have offered asylum to unprecedented numbers of refugees, particularly those fleeing conflict in North Africa and the Middle East. For Europe, this culminated in a 'refugee crisis' in the summer and autumn of 2015. The question of how non-economic immigrants adjust to life in the host country has rarely been more important for government policy or for human welfare.

My primary finding is that refugees and family immigrants are substantially more likely to report the host national identity than economic or student immigrants. A large part of this elevated tendency is explained by differences in observed demographic and human capital characteristics, but even after accounting for such differences, family immigrants and refugees remain around 13 and $8 \%$ more likely to report a host national identity respectively. These two groups still remain more likely to report the host national identity when restricting the analysis to immigrants without citizenship, to those with only weak incentives to acquire citizenship, or to those from origin countries without linguistic or cultural connections to the UK via the British Commonwealth.

\section{Related literature}

Identity is a topic of central importance for social scientists. Although it is not seen as a traditional area of interest for economists, a theoretical literature on the subject has been building in the discipline for two decades (Akerlof 1997; Akerlof and Kranton 2000, 2002, 2005; Battu et al. 2007; Bénabou and Tirole 2011; Bisin et al. 2011b, 2016; Kranton 2016), drawing principally on earlier work in sociology and social psychology (Berry 1997; Merton 1968; Tajfel and Turner 1979; Wetherell 1996). A body of empirical work in economics is also now becoming well established (Bernhard et al. 2006; Chen and Li 2009; Costa i Font and Cowell 2015; DepetrisChauvin et al. 2018).

The dominant view of identity applied in economics comes from Akerlof and Kranton (2000). In this approach, identity is person's sense of self, arising partly from the social categories to which she belongs. Social categories may emerge on the basis of characteristics such as gender, ethnicity, or language, as well as nationality. Each social category is associated with different behavioural norms, and following these norms is rewarding for the individual, while deviation can generate disutility for the individual and for others. By shaping the rewards associated with different 
actions in this way, identity is implicated in a wide range of economic and social behaviour for individuals and groups.

National identity is a particularly important aspect of identity since, through its influence on intergroup behaviour, it relates to the functioning of societies as a whole. This is especially the case where a country is ethnically diverse or has a large immigrant population. In such countries, some individuals may maintain a minority ethnic or national identity, either exclusively or in addition to adopting the identity of the majority. These minority identities have often been seen as a potential source of economic inefficiency. For this reason, one strand of work examines the role of minority identity in labour market performance (Battu and Zenou 2010; Bisin et al. 2011a; Constant et al. 2006; Drydakis 2013; Islam and Raschky 2015; Mason 2004; Nekby and Rödin 2010, Pendakur and Pendakur 2005), while another examines minority identity and educational attainment (Nekby et al. 2009; Schüller 2015).

Several authors have applied a version of Berry's (1997) two-dimensional acculturation framework in this setting, distinguishing between four strategies that immigrants or ethnic minority individuals may choose for interaction with the majority society: 'integration', 'assimilation', 'separation', and 'marginalisation' (Constant et al. 2006; Constant and Zimmermann 2008; Drydakis 2013; Nekby and Rödin 2010; Nekby et al. 2009). 'Integration' describes the case where a minority individual takes on the identity of the majority but maintains her own minority identity. 'Assimilation' is where she takes on the majority identity and abandons the minority identity. 'Separation' is where she maintains only the minority identity, and 'marginalisation' is where she maintains neither the majority nor minority identities. In most studies, 'integration' and 'assimilation' are seen to produce the most desirable outcomes for both the immigrant and the host society, while 'separation' and 'marginalisation' are seen to be the least desirable.

While work on labour market and educational outcomes suggests that identity is important in the economic lives of immigrants, only a handful of papers address the determinants of immigrant identity itself. A large proportion use data from Germany. One early example is Dustmann (1996), who shows that adoption of the host identity among immigrants in Germany is associated with factors which increase exposure to the host society, such as age on arrival, years of residence, language fluency, educational background, and the presence of children. Constant and Zimmermann (2008) and Constant et al. (2009) demonstrate the importance of pre-migration characteristics such as religion, home country education, and country of origin. Casey and Dustmann (2010) add that immigrant national identity is correlated across generations, which suggests that exposure to a particular national identity within the home may also be important.

In the UK, Georgiadis and Manning (2013) show that immigrants and minority groups in England and Wales are more likely to identify as British if they report feeling tolerated and respected by the majority society, while Manning and Roy (2010) find that immigrants to Great Britain from poor and less democratic countries tend to adopt the British national identity more readily than others. In this latter case, the authors suggest that uptake of the host identity is driven partly by a favourable comparison of the host country with the home country in economic and political terms. 
No study so far has linked the adoption of a new national identity to the average time horizons of different immigrant groups. This is surprising, given the large body of work linking immigrant time horizons to other country-specific investments (see Dustmann and Görlach 2016, for a recent review). The key insight from this work is that temporary immigrants face weaker incentives to invest in country-specific human capital than permanent immigrants, since the expected return on this human capital is necessarily lower for those who plan to re-migrate (Dustmann 1993, 1999, 2008). Temporary immigrants are therefore less likely to spend time and money acquiring the native language or building networks of social contacts, and are less likely to bear the cost of bringing their families to the host country with them (Adda et al. 2015).

An important innovation in the literature on immigrant time horizons is due to Cortes (2004), who connects these insights on temporary migration to differences between immigrant groups, comparing earnings assimilation trajectories for economic and refugee immigrants in the USA. She observes that implicit differences in time horizons between these immigrant groups are reflected in their human capital accumulation activities and rates of earnings assimilation (Borjas 1982, and Khan 1997, make similar observations). Cortes (2004) cites "fear or threat of persecution" in the home country as the principal reason that refugees may have longer average time horizons in the host country, though it is possible there are other factors that raise the cost of leaving for this particular immigrant group, such as a lack of possible third-country destinations. As I note above, family immigrants also face additional costs of migration on arrival and on departure from the host country, due to the coordinated nature of family migration.

If family immigrants and refugees do tend to have longer time horizons in the host country than economic immigrants, and if national identity behaves in the same way as other country-specific investments, then it seems reasonable to hypothesise that family immigrants and refugees will be more likely to report a host national identity than economic immigrants. This should be the case even where immigrants from the different groups are similar in a range of other characteristics already emphasized in the literature as determinants of immigrant national identity, such as exposure to the host society and characteristics of the home country. Student immigrants have been relatively neglected in the migration literature as a whole, but given that most presumably first arrive with the intention only to complete a qualification before returning to the home country, one might expect this group to have short time horizons in the host country, and therefore have a relatively low propensity to report the host national identity.

One reason for the apparent lack of research linking national identity to the time horizons of different immigrant groups may be that data directly identifying these groups are rare, and indirect methods of identifying them carry the risk of substantial measurement error. For example, Cortes (2004) infers refugee status from country of origin and year of arrival, but this method would falsely identify a large number of cases in the UK context, since only a small proportion of immigrants from any particular country arrive as refugees in any given year (Bell et al. 2013). In this paper, I am able to overcome substantial problems of measurement error by using a direct survey measure of immigrant group. This allows me to combine insights from the 
literature on time horizons with emerging work on the determinants of immigrant national identity.

\section{Data}

\subsection{Sample construction}

My data come from the UK Labour Force Survey (LFS) between January 2010 and October 2017 (Office for National Statistics 2018). The LFS is the UK's largest regular household survey, with around 40,000 responding households every calendar quarter. The survey records responses from a stratified random sample of addresses five times over a one year period, with a fifth of the survey rotating to a new sample of addresses in each quarter. Households are approached at all waves of the survey whether or not they have responded previously, but are not followed if they move to a new address.

There is insufficient variation in national identity over the five waves of the survey to make use of the panel aspect of the data. ${ }^{1}$ However, I am able to use the different waves of the survey to increase the size of the cross-sectional sample. I prioritise those who respond in Wave 1 of the survey, since this wave has the highest response rate. I then expand the sample by seeking a non-missing observation on those who missed the first wave sequentially in Waves 2, 3, 4, and 5. Due to the large proportion of immigrants who miss the first wave of the survey but appear at some point in later waves, this strategy covers around $40 \%$ more immigrants than the more commonlyused alternative strategy of using the first wave alone.

Unfortunately, the data do not consistently identify which respondents are sharing the same household. This means that I cannot separate family immigrants who share a household with those from other immigrant groups, and I cannot cluster standard errors at the household level. In addition, around a third of responses in the LFS are by proxy. I exclude these proxy responses on the grounds that an individual's national identity may be imperfectly observed by others, even close family members. I also restrict the sample to foreign-born adults aged at least 16, on whom I have information on national identity along with the full-set of explanatory variables discussed below. ${ }^{2}$ My final analytical sample consists of 76,024 immigrants.

\subsection{National identity}

All respondents to the LFS are asked 'How would you describe your national identity? Please choose all that apply'. ${ }^{3}$ They may choose from the constituent

\footnotetext{
${ }^{1}$ Less than $2 \%$ of adult immigrant respondents change their reported identity over the five waves of the LFS.

2 The exception is the 'years of education' variable, which is missing for around 7\% of respondents. I use a missing dummy to account for this in the regressions below.

${ }^{3}$ The wording of this question was slightly different before 2011: 'What do you consider your national identity to be? Please choose as many as apply.' Residents of Northern Ireland were not asked about national identity before 2011 .
} 
national identities of the UK ('English', 'Scottish', 'Welsh', and 'Northern Irish'), and additional categories for 'British' and 'Other'. I group respondents who report a British national identity with those who report an English, Scottish, Welsh, or Northern Irish identity. ${ }^{4}$ Around $5 \%$ of the sample report both a British and a foreign national identity, and I include these individuals as 'British', on the grounds that they have adopted the host identity in some sense. In Berry's (1997) acculturation framework, the outcome I examine can therefore be considered mostly an indicator of identity 'assimilation', with some cases of 'integration'. This is contrasted only with identity 'separation', since there is no way to observe a 'marginalised' identity in these data, due to the form of the survey question. This is a sensible simplification of the two-dimensional acculturation framework for my purposes, since the value of adopting the host identity should vary for different immigrant groups in response to different average time horizons, regardless of whether the home identity is maintained. Table 4 in the Appendix shows results with 'assimilation' and 'separation' as separate outcomes. The key group differences are larger in relative terms when using 'integration' alone as the outcome variable, although the base probability of reporting an 'integrated' identity is low.

National identity is a multidimensional concept with legal, affective, and ethnic components, and respondents may be influenced by any or all of these components when answering the survey question (Heath and Tilley 2005; Nandi and Platt 2015). For example, a respondent may be inclined to report a British national identity on the basis of her legal status or citizenship. She may also be influenced by affective factors arising from contact and experiences with the host society, or she may include or exclude herself on the basis of her ethnicity. I aim to account for factors which predict each of these dimensions of national identity in my empirical specification below.

Some authors have suggested that binary questions about national identity such as that in the LFS may lack the precision required to capture identity as distinct from legal citizenship (Manning and Roy 2010; Nandi and Platt 2015; Platt 2014). Partly in response to these concerns, Georgiadis and Manning (2013) compare a binary national identity question similar to that in the LFS with a more detailed set of related questions in the British Citizenship Survey, which attempt to the gauge the strength rather than simply the direction of national identification. These questions include whether each respondent feels she is "...part of British society" and how strongly she feels she "...belong[s] to Britain". The authors find similar patterns of response to all of these questions, which suggests that binary measures are able to capture aspects of identity beyond legal citizenship. I show below that my results are similar when restricting the analysis to non-citizens.

Georgiadis and Manning (2013) also show that people are less likely to report the host national identity if they feel that they are discriminated against. The LFS does not ask questions about perceived discrimination, but it is possible that refugees face stronger discrimination than other immigrant groups in the UK (Bloch 2008; Duke 1996). The implication is that my estimates of the prevalence of host country identity

\footnotetext{
${ }^{4}$ Around $6 \%$ of the sample report an English, Scottish, Welsh, or Northern Irish identity, compared to $38 \%$ who report a British identity.
} 
in the refugee group may be attenuated compared to others, since I am unable to account for differential discriminatory experiences with these data.

\subsection{Immigrant groups}

Since January 2010, foreign-born respondents in the LFS have been asked 'What was your main reason for coming to the UK?'. They may give only one of 8 possible responses. ${ }^{5}$ I define economic immigrants as those who say they came 'For employment', student immigrants as those who say they came 'For study', family immigrants as those who say they came for one of three family-related reasons ('To get married/form a civil partnership'; 'As a spouse/dependent of a UK citizen'; and 'As a spouse/dependent of someone coming to UK' $){ }^{6}$ and refugees as those who say they came 'Seeking asylum'. 7 Finally, I combine those who said they either came 'As a visitor' or for 'Other reasons' into an 'other' category.

This key question concerns the 'main reason' for coming to the country, rather than the legal channel through which a person entered. However, the response categories do broadly correspond with legal channels for entry, and it is therefore possible that some respondents give their original legal channel, while others respond with their true 'main reason'. In particular, immigrants who do not require a visa, such as those from European Union countries, may give their true main reason, while those from outside the European Union may be more inclined to give their legal entry channel. Both legal entry channel and true main reason seem likely to correspond to the group differences of interest, so this potential ambiguity in the question does not lead me to anticipate a particular bias in one direction or the other. I show results with EU and non-EU immigrants separated below.

The LFS does not survey 'communal establishments' such as hotels, hostels, or university accommodation, and language difficulties or nervousness about responding to government surveys may also make some people less willing to respond. These feature of the survey mean that recent immigrants of all types are likely to be under-sampled, but the exclusion of communal establishments is likely to disproportionately reduce the sample of recent international students, and recent refugees may be more affected by language difficulties or reluctance to participate than other groups (Office for National Statistics 2007). If those who miss the survey at this stage are less likely to hold a British identity than those who participate, my key estimates for these groups may be biased upwards.

Since the UK is a rich country with a restrictive work visa regime, some measurement error could plausibly arise from economic migrants answering that they came primarily for one of the non-economic reasons. This might be the case if the respondent felt that being an economic immigrant was less socially desirable, or if

\footnotetext{
${ }^{5}$ Less than $1 \%$ of adult immigrant respondents change their 'main reason' over the five waves of the LFS.

6 From 2015, 'To get married/form a civil partnership' was dropped, and the two other family-related options were modified slightly. They became 'As a spouse/partner/child under 18 of a UK citizen or person with indefinite leave to remain in the UK' and 'As a spouse/partner/child under 18 of someone coming into the UK or already living here, who does not have indefinite leave to remain'.
}

7 See Ruiz and Vargas-Silva (2018) for a discussion of the different legal definitions of 'refugee' and 'asylum seeker' in the UK. 


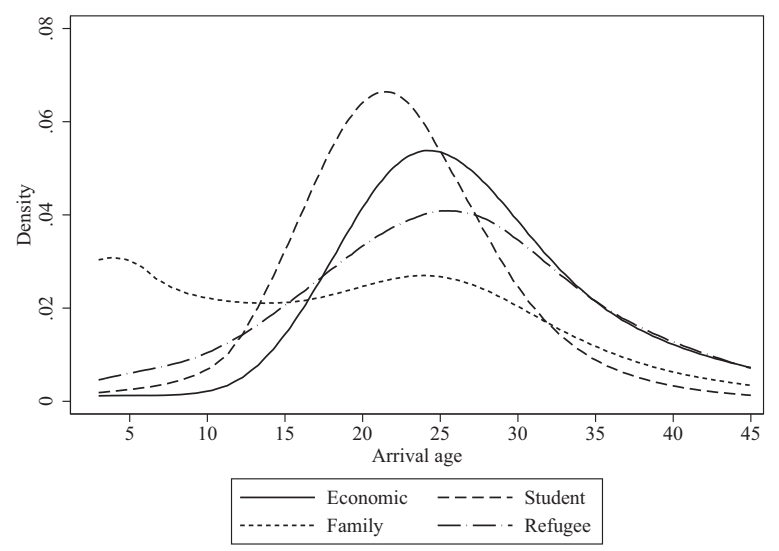

Fig. 1 Distribution of age on arrival by immigrant group. Source, LFS, 2010-2017. $n=76,024$. This chart shows kernel density estimates of age on arrival for economic, student, family, and refugee immigrants. Notes: Foreign-born respondents aged 16 and over. Distributions are not shown before the arrival age of 2 or beyond the arrival age of 45 in order to protect the confidentiality of respondents, in line with the requirements of the data provider

she arrived in a non-economic visa category, and felt that revealing an economic motive in a government survey would carry legal risks. The overall effect of this measurement error would be to make the economic and non-economic immigrant categories more similar, attenuating the key differences I report.

As an informal check on the immigrant groups produced by this survey measure, Fig. 1 shows kernel density estimates of age on arrival for economic, student, family, and refugee immigrants. One would generally expect the arrival of student immigrants to be concentrated around university age, while the arrival of economic migrants should be concentrated on working age, and the arrival of family immigrants and refugees should be spread more evenly across different age groups. Consistent with these expectations, Fig. 1 shows that those who identify themselves as student immigrants most often arrive in their early twenties, while those who identify themselves as economic immigrants are more concentrated in their midtwenties on arrival. Refugee and family arrivals are both more evenly spread across younger and older ages. Family arrivals peak in the pre-school age group as well as in the mid-20s, as this group contains both those who migrated as young children with parents, and those who migrated as adults with partners or other family members.

As an additional check on the plausibility of the refugee group identified by this measure, Fig. 2 compares the frequency of arrival years among refugees in the sample (on the left axis) with the aggregate number of 'grants of asylum' per year reported by the UK government (on the right axis). Again, this is only an approximate indication, but the pattern of arrival years in the sample clearly echoes the aggregate government data up to around 2005. After this point there is a divergence between the two series, with grants of asylum rising while the frequency of arrival years in the sample declines. This may reflect the difficulty of sampling recent immigrants in the LFS, and particularly refugees (Office for National Statistics 2007). 


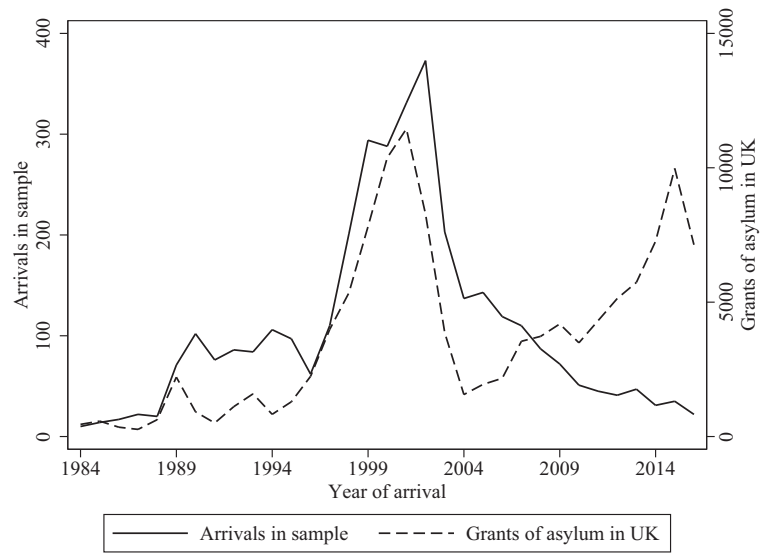

Fig. 2 Comparison of refugee arrival years in sample with grants of asylum. Source, LFS, 2010-2017 and Home Office (2018b). This chart compares the frequency of arrival years among refugees in the sample (on the left axis) with the aggregate number of grants of asylum per year reported by the UK government (on the right axis) between 1984 and 2016. Frequencies are not shown before 1984 or beyond 2016 in order to protect the confidentiality of respondents, in line with the requirements of the data provider

\section{Characteristics of the different immigrant groups}

I report selected demographic and human capital characteristics of each immigrant group in Table 1. Compared with economic immigrants, family immigrants and refugees are more likely to be from an ethnic minority and are more likely to be from an origin country outside the EU. Around $44 \%$ of all immigrants report a British national identity: $25 \%$ of economic immigrants, $31 \%$ of student immigrants, $62 \%$ of family immigrants, and 53\% of refugees. These are substantial differences, and in line with expectations based on implied differences in time horizons.

There are other indications in Table 1 that family immigrants and refugees tend to have longer time horizons in the UK. Around 39\% of family immigrants and 49\% of refugees have dependent children in their household, compared to $36 \%$ of economic immigrants. Having children generally indicates a longer intended stay, since it makes both migration and return migration more costly (Dustmann and Görlach 2016). Table 1 also shows that around 61 and 54\% of family immigrants and refugees have taken up British citizenship, compared to $23 \%$ of economic immigrants. ${ }^{8}$ Citizenship gives individuals the permanent right to live in the UK, and the right to vote in UK elections. However, the process of acquiring citizenship can be costly: the fee in 2018 is over $£ 1300$, and most applicants must have lived in the UK for at least five years, must not have a recent criminal record, and must be able to pass both a language test and a test of cultural knowledge (these fees and requirements of citizenship are lower for spouses of British citizens, and for those who arrive under the age of 18) (Home Office 2018a). For most immigrants, the

\footnotetext{
${ }^{8}$ Respondents are asked "What is your nationality?" This is usually interpreted as a question about citizenship, although it is possible that some respondents associate 'nationality' with ethnicity or country of birth.
} 
Table 1 Selected characteristics of sample by immigrant group

\begin{tabular}{|c|c|c|c|c|c|c|}
\hline & Economic & Student & Family & Refugee & Other & Total \\
\hline \multicolumn{7}{|l|}{ National identity } \\
\hline British & $\begin{array}{l}0.25 \\
(0.43)\end{array}$ & $\begin{array}{l}0.31 \\
(0.46)\end{array}$ & $\begin{array}{l}0.62 \\
(0.48)\end{array}$ & $\begin{array}{l}0.53 \\
(0.50)\end{array}$ & $\begin{array}{l}0.50 \\
(0.50)\end{array}$ & $\begin{array}{l}0.44 \\
(0.50)\end{array}$ \\
\hline \multicolumn{7}{|c|}{ General demographic and human capital characteristics } \\
\hline Female & $\begin{array}{l}0.43 \\
(0.50)\end{array}$ & $\begin{array}{l}0.49 \\
(0.50)\end{array}$ & $\begin{array}{l}0.66 \\
(0.47)\end{array}$ & $\begin{array}{l}0.43 \\
(0.50)\end{array}$ & $\begin{array}{l}0.56 \\
(0.50)\end{array}$ & $\begin{array}{l}0.54 \\
(0.50)\end{array}$ \\
\hline Years since migration & $\begin{array}{l}16.24 \\
(17.82)\end{array}$ & $\begin{array}{l}14.84 \\
(15.31)\end{array}$ & $\begin{array}{l}28.14 \\
(19.96)\end{array}$ & $\begin{array}{l}15.88 \\
(12.14)\end{array}$ & $\begin{array}{l}24.70 \\
(19.45)\end{array}$ & $\begin{array}{l}21.36 \\
(19.16)\end{array}$ \\
\hline Age on arrival & $\begin{array}{l}27.42 \\
(8.71)\end{array}$ & $\begin{array}{l}22.40 \\
(6.56)\end{array}$ & $\begin{array}{l}17.95 \\
(13.76)\end{array}$ & $\begin{array}{l}26.79 \\
(11.74)\end{array}$ & $\begin{array}{l}25.07 \\
(14.70)\end{array}$ & $\begin{array}{l}22.84 \\
(12.19)\end{array}$ \\
\hline Years of education $(\mathrm{UK})^{\mathrm{a}}$ & $\begin{array}{l}0.47 \\
(2.26)\end{array}$ & $\begin{array}{l}2.32 \\
(3.61)\end{array}$ & $\begin{array}{l}6.00 \\
(7.36)\end{array}$ & $\begin{array}{l}1.49 \\
(3.96)\end{array}$ & $\begin{array}{l}2.77 \\
(5.78)\end{array}$ & $\begin{array}{l}3.11 \\
(5.80)\end{array}$ \\
\hline Years of education (Foreign) ${ }^{\mathrm{a}}$ & $\begin{array}{l}12.86 \\
(4.91)\end{array}$ & $\begin{array}{l}13.57 \\
(4.72)\end{array}$ & $\begin{array}{l}7.38 \\
(6.62)\end{array}$ & $\begin{array}{l}9.89 \\
(5.61)\end{array}$ & $\begin{array}{l}9.83 \\
(6.17)\end{array}$ & $\begin{array}{l}10.47 \\
(6.32)\end{array}$ \\
\hline Missing education information & $\begin{array}{l}0.08 \\
(0.27)\end{array}$ & $\begin{array}{l}0.04 \\
(0.19)\end{array}$ & $\begin{array}{l}0.08 \\
(0.27)\end{array}$ & $\begin{array}{l}0.06 \\
(0.23)\end{array}$ & $\begin{array}{l}0.11 \\
(0.31)\end{array}$ & $\begin{array}{l}0.07 \\
(0.26)\end{array}$ \\
\hline In full-time education & $\begin{array}{l}0.02 \\
(0.13)\end{array}$ & $\begin{array}{l}0.29 \\
(0.45)\end{array}$ & $\begin{array}{l}0.07 \\
(0.25)\end{array}$ & $\begin{array}{l}0.09 \\
(0.28)\end{array}$ & $\begin{array}{l}0.03 \\
(0.18)\end{array}$ & $\begin{array}{l}0.08 \\
(0.28)\end{array}$ \\
\hline Citizen & $\begin{array}{l}0.23 \\
(0.42)\end{array}$ & $\begin{array}{l}0.30 \\
(0.46)\end{array}$ & $\begin{array}{l}0.61 \\
(0.49)\end{array}$ & $\begin{array}{l}0.54 \\
(0.50)\end{array}$ & $\begin{array}{l}0.48 \\
(0.50)\end{array}$ & $\begin{array}{l}0.43 \\
(0.49)\end{array}$ \\
\hline Has kids $^{\mathrm{a}}$ & $\begin{array}{l}0.36 \\
(0.48)\end{array}$ & $\begin{array}{l}0.29 \\
(0.45)\end{array}$ & $\begin{array}{l}0.39 \\
(0.49)\end{array}$ & $\begin{array}{l}0.49 \\
(0.50)\end{array}$ & $\begin{array}{l}0.32 \\
(0.47)\end{array}$ & $\begin{array}{l}0.36 \\
(0.48)\end{array}$ \\
\hline \multicolumn{7}{|l|}{ Ethnicity } \\
\hline White & $\begin{array}{l}0.66 \\
(0.47)\end{array}$ & $\begin{array}{l}0.35 \\
(0.48)\end{array}$ & $\begin{array}{l}0.46 \\
(0.50)\end{array}$ & $\begin{array}{l}0.13 \\
(0.34)\end{array}$ & $\begin{array}{l}0.56 \\
(0.50)\end{array}$ & $\begin{array}{l}0.50 \\
(0.50)\end{array}$ \\
\hline Black African or Caribbean & $\begin{array}{l}0.08 \\
(0.27)\end{array}$ & $\begin{array}{l}0.15 \\
(0.36)\end{array}$ & $\begin{array}{l}0.11 \\
(0.32)\end{array}$ & $\begin{array}{l}0.35 \\
(0.48)\end{array}$ & $\begin{array}{l}0.15 \\
(0.36)\end{array}$ & $\begin{array}{l}0.12 \\
(0.33)\end{array}$ \\
\hline Indian/Pakistani/Bangladeshi & $\begin{array}{l}0.13 \\
(0.34)\end{array}$ & $\begin{array}{l}0.18 \\
(0.39)\end{array}$ & $\begin{array}{l}0.28 \\
(0.45)\end{array}$ & $\begin{array}{l}0.10 \\
(0.31)\end{array}$ & $\begin{array}{l}0.15 \\
(0.35)\end{array}$ & $\begin{array}{l}0.19 \\
(0.40)\end{array}$ \\
\hline Mixed/Other & $\begin{array}{l}0.13 \\
(0.34)\end{array}$ & $\begin{array}{l}0.31 \\
(0.46)\end{array}$ & $\begin{array}{l}0.15 \\
(0.36)\end{array}$ & $\begin{array}{l}0.42 \\
(0.49)\end{array}$ & $\begin{array}{l}0.15 \\
(0.35)\end{array}$ & $\begin{array}{l}0.18 \\
(0.38)\end{array}$ \\
\hline \multicolumn{7}{|l|}{ International region of origin } \\
\hline EU & $\begin{array}{l}0.57 \\
(0.50)\end{array}$ & $\begin{array}{l}0.26 \\
(0.44)\end{array}$ & $\begin{array}{l}0.26 \\
(0.44)\end{array}$ & $\begin{array}{l}0.03 \\
(0.18)\end{array}$ & $\begin{array}{l}0.32 \\
(0.47)\end{array}$ & $\begin{array}{l}0.35 \\
(0.48)\end{array}$ \\
\hline Africa & $\begin{array}{l}0.09 \\
(0.29)\end{array}$ & $\begin{array}{l}0.18 \\
(0.39)\end{array}$ & $\begin{array}{l}0.16 \\
(0.36)\end{array}$ & $\begin{array}{l}0.40 \\
(0.49)\end{array}$ & $\begin{array}{l}0.23 \\
(0.42)\end{array}$ & $\begin{array}{l}0.16 \\
(0.37)\end{array}$ \\
\hline Asia & $\begin{array}{l}0.20 \\
(0.40)\end{array}$ & $\begin{array}{l}0.39 \\
(0.49)\end{array}$ & $\begin{array}{l}0.38 \\
(0.48)\end{array}$ & $\begin{array}{l}0.38 \\
(0.48)\end{array}$ & $\begin{array}{l}0.20 \\
(0.40)\end{array}$ & $\begin{array}{l}0.30 \\
(0.46)\end{array}$ \\
\hline Elsewhere & $\begin{array}{l}0.14 \\
(0.35)\end{array}$ & $\begin{array}{l}0.17 \\
(0.37)\end{array}$ & $\begin{array}{l}0.21 \\
(0.40)\end{array}$ & $\begin{array}{l}0.19 \\
(0.40)\end{array}$ & $\begin{array}{l}0.24 \\
(0.43)\end{array}$ & $\begin{array}{l}0.18 \\
(0.39)\end{array}$ \\
\hline
\end{tabular}

Country groups 
Table 1 continued

\begin{tabular}{lllllll}
\hline & Economic & Student & Family & Refugee & Other & Total \\
\hline Non-EU origin country & 0.43 & 0.74 & 0.74 & 0.97 & 0.68 & 0.65 \\
& $(0.50)$ & $(0.44)$ & $(0.44)$ & $(0.18)$ & $(0.47)$ & $(0.48)$ \\
Commonwealth origin country & 0.29 & 0.42 & 0.54 & 0.27 & 0.48 & 0.42 \\
& $(0.45)$ & $(0.49)$ & $(0.50)$ & $(0.44)$ & $(0.50)$ & $(0.49)$ \\
Requires Visa to visit UK & 0.33 & 0.57 & 0.57 & 0.91 & 0.50 & 0.50 \\
& $(0.47)$ & $(0.50)$ & $(0.50)$ & $(0.28)$ & $(0.50)$ & $(0.50)$ \\
Sample composition & & & & & 0.11 & 1.00 \\
Proportion of sample & 0.31 & 0.16 & 0.37 & 0.05 & 0.11 & 76,024 \\
$n$ & 23,619 & 11,784 & 28,166 & 3910 & 8545 & \\
\hline
\end{tabular}

Source: LFS 2010-2017. Notes: Foreign-born respondents aged 16 and over. Sample means and standard deviations (in parenthesis)

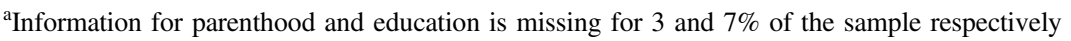

investment in citizenship will only be worthwhile if they intend to stay in the host country for a substantial period of time.

\subsection{Identity assimilation trajectories and selective attrition}

Figure 3 shows the proportion of each immigrant group reporting a British national identity over years since migration. Almost no one who is newly arrived in the country reports a British national identity. The higher level of British identity among family immigrants and refugees emerges among those who have been in the country less than 5 years, and just over $80 \%$ of those who have been in the country for 40 years or longer identify as British. Economic immigrants who have been in the country for a longer time are also more likely to report a British national identity, but the gradient is less dramatic, and just over $60 \%$ identify as British after 40 years in the country. Student immigrants who have been in the country for 5 years are similar to economic immigrants in their level of British identity, but their gradient is steeper after this point, and student immigrants who have been in the country for at least 40 years look more like family immigrants and refugees in this respect.

Figure 3 does not show pure identity assimilation trajectories. Given that this sample is a pooled cross-section, both the overall rate of identity assimilation, and that of the different immigrant groups, are likely to be affected by selective attrition. In general, if immigrants who feel less British are more likely to return to their origin country over time, then the proportion of immigrants who report a British national identity will rise over years since migration without any causal effect of time in the country. The key question for my purposes is whether the heightened identityassimilation of family immigrants and refugees at a given number of years in the host country is produced purely by differential selective attrition rather than by differences in the propensity to take up the host identity. Although it is not possible to exclude this possibility with cross-sectional data, it does not seem likely. Indeed, the bias seems more likely in the other direction. The limited administrative data that exist in the UK suggest that there are high outflows of both economic and student immigrants 


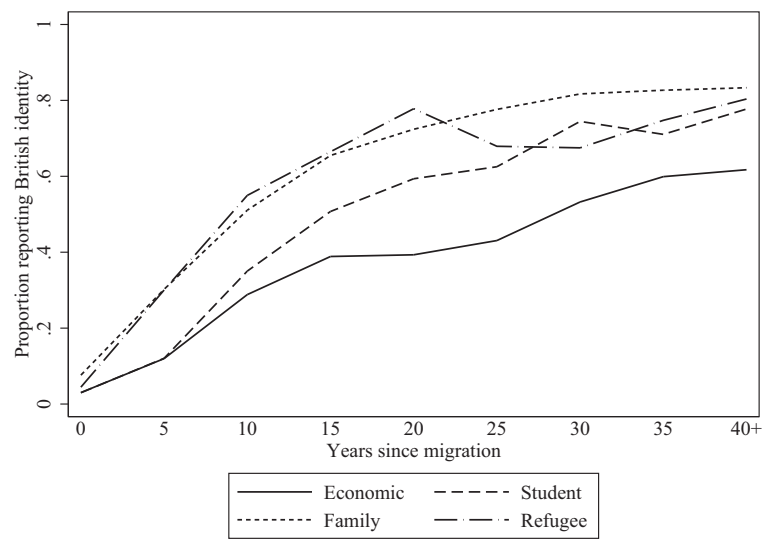

Fig. 3 Proportion of each immigrant group reporting British national identity over years since migration. Source, LFS, 2010-2017. $n=76,024$. Notes: Foreign-born respondents aged 16 and over. Averages by group at 5 year intervals

over time (Home Office 2014). If these outflows consist disproportionately of those who feel less British, then the rate of identity assimilation for economic and student immigrants will be boosted relative to refugees and family immigrants, who are less likely to leave the country (Bijwaard 2010; Home Office 2014). As with the effect of potential measurement error in the immigrant categories, the implication is that differential selective attrition attenuates the key differences in national identity I report.

\section{Results}

In this section, I assess the extent to which differences in national identity between immigrant groups are driven by their distinct observable characteristics. I estimate a probit model of the form

$$
\operatorname{prob}\left(\mathrm{BRITISH}_{i}=1\right)=\Phi\left(\begin{array}{c}
\alpha+\beta_{1} \text { STUDENT }_{i}+ \\
\beta_{2} \text { FAMILY }_{i}+\beta_{3} \text { REFUGE }_{i} \\
+\beta_{4} \text { OTHER }_{i}+\gamma X_{i}
\end{array}\right)
$$

where BRITISH is a dummy variable taking a value of 1 if individual $i$ reports a British national identity. STUDENT, FAMILY, REFUGEE, and OTHER are dummy variables representing membership of each immigrant group, with economic immigrants acting as the reference category. $\mathrm{X}$ represents a vector of control variables, including gender, ${ }^{9}$ year of survey, and 'currently in full-time education'.

I include 3 controls for ethnicity ('Black African or Caribbean', 'Indian/Pakistani/ Bangladeshi', and 'Mixed/Other'), with 'White' as the reference category. I note above that respondents may include or exclude themselves from the host identity on

\footnotetext{
9 The same proportion of men and women in the sample report a British identity (44\%), and the key estimates are comparable when estimated separately by gender. See Table 5 in the Appendix.
} 
the basis of their own ethnicity, and minority status is also linked to the experience of discrimination, which is shown elsewhere to reduce identification with the host society (Georgiadis and Manning 2013). In order to account for the influence of exposure to the host society, as emphasized by Dustmann (1996), I include a quartic in age of arrival, and a quartic in years since migration. Figures 4 and 5 in the Appendix show that these quartic terms capture the identity assimilation process well, when compared with using separate dummies for each year. I omit age and year of arrival, since the influence of these factors cannot be separately identified from those for age on arrival, years since migration, and year of survey. I also include quadratic terms in years of accumulated domestic and foreign education, to account both for any direct influence of education on identity, and for the close form of societal exposure that host-country education implies.

Origin country is a particularly important feature of the model. It can account for the circumstances of a respondent's legal relationship with the UK, such as visa availability and restrictions, as well as access to UK citizenship. It can also account for the influence of any historical or cultural affinity or enmity between the origin country and the UK, and the size of an immigrant's potential community of conationals. There may also be origin-country-level variation in the understanding of national identity itself. For example, given conventions in the home country, immigrants from France may consider the legal dimension more important in choosing an identity, while those from Germany may consider ethnicity more important (see Kiss and Park 2014, on these national differences in the concept of national identity). As far as sample size will allow, I therefore control for each individual origin country. I am able to do so for 132 countries (covering around $98 \%$ of the sample), and I account for the remainder with four broad controls for international region of origin (EU, Africa, Asia, Elsewhere). In my preferred specification, I also interact each of these origin dummies with the quartic in years since migration, in order to allow different identity assimilation trajectories for immigrants from different countries who have been in the UK for a similar length of time.

Economic outcomes such as employment status or wages could plausibly be important in the adoption of a new national identity for immigrants. Such outcomes may be a particular concern when comparing national identity across different immigrant groups, since refugees and family immigrants are sometimes more likely to struggle on the labour market than others (Aydemir 2011; Bevelander and Pendakur 2014; Cobb-Clark 2006; DeVoretz et al. 2005; Ruiz and Vargas-Silva 2018). However, controlling for economic outcomes may be problematic, since, like the adoption of a new national identity, they represent outcomes of the immigrant assimilation process. I therefore omit them from my preferred model, but present results with employment and pay controls in Table 6 in the Appendix for reference. The main coefficients of interest are unaffected by controlling for employment status, and rise slightly when controlling for weekly pay. ${ }^{10}$ This is consistent with results controlling for economic outcomes reported in Dustmann (1996) and Manning and Roy (2010).

${ }^{10}$ Due to the design of the LFS, controlling for weekly pay is only possible for a subset of employed respondents who are not self-employed, and who are interviewed in the first or fifth waves of the survey. 
The key estimates produced by my approach $\left(\beta_{1}, \beta_{2}\right.$, and $\left.\beta_{3}\right)$ represent average differences in British national identity between economic immigrants and each noneconomic immigrant group, after accounting for observed differences in characteristics represented by the control variables I discuss above. They are conditional correlations rather than causal estimates, and should be viewed as a way of assessing whether the data are consistent with my observations on immigrant groups, time horizons, and national identity. This approach is unable to separate differences between immigrant groups which emerge in the host country from those which are pre-existing in the origin county. For example, through some process of self-selection, it is possible that refugees and family immigrants arrive in the UK already more or less inclined to adopt a British national identity than those in other immigrant groups. However, establishing the size of any potential group differences in national identity is my primary objective, and whether these differences emerge predominantly before or after migration is not crucial for this exercise. Indeed, it is plausible that group differences in average time horizons could emerge almost entirely before migration takes place.

\subsection{Baseline results}

Table 2 shows the key average marginal effects from estimating model (1). Column 1 shows results with only controls for year of survey, Column 2 shows results with additional controls for demographic and human capital characteristics, age on arrival, and years since migration. Column 3 shows results with controls for country of origin. Results from my preferred model with origin controls interacted with years

Table 2 Baseline results: Average marginal effects from models of British national identity

\begin{tabular}{|c|c|c|c|c|c|}
\hline & (1) & (2) & (3) & (4) & (5) \\
\hline Economic & REF & REF & REF & REF & REF \\
\hline \multirow[t]{2}{*}{ Student } & 0.060 & 0.029 & 0.004 & 0.001 & 0.001 \\
\hline & $(0.005)^{* * * *}$ & $(0.005)^{* * *}$ & $(0.005)$ & $(0.005)$ & $(0.009)$ \\
\hline \multirow[t]{2}{*}{ Family } & 0.372 & 0.097 & 0.057 & 0.053 & 0.053 \\
\hline & $(0.004)^{* * * *}$ & $(0.004)^{* * *}$ & $(0.004)^{* * * *}$ & $(0.004)^{* * *}$ & $(0.007)^{* * * *}$ \\
\hline \multirow[t]{2}{*}{ Refugee } & 0.272 & 0.112 & 0.038 & 0.031 & 0.031 \\
\hline & $(0.008)^{* * * *}$ & $(0.007)^{* * * *}$ & $(0.007)^{* * * *}$ & $(0.007)^{* * * *}$ & $(0.013)^{*}$ \\
\hline \multirow[t]{2}{*}{ Other } & 0.246 & 0.078 & 0.036 & 0.033 & 0.033 \\
\hline & $(0.006)^{* * *}$ & $(0.005)^{* * * *}$ & $(0.005)^{* * *}$ & $(0.005)^{* * *}$ & $(0.007)^{* * *}$ \\
\hline \multirow[t]{2}{*}{ Base probability } & 0.252 & 0.382 & 0.411 & 0.413 & 0.413 \\
\hline & $(0.003)^{* * * *}$ & $(0.003)^{* * * *}$ & $(0.003)^{* * *}$ & $(0.003)^{* * *}$ & $(0.005)^{\text {**** }}$ \\
\hline \multicolumn{6}{|l|}{ Controls } \\
\hline Personal characteristics & - & Yes & Yes & Yes & Yes \\
\hline Origin & - & - & Yes & Yes & Yes \\
\hline Origin*ysm & - & - & - & Yes & Yes \\
\hline Clustering on origin & - & - & - & - & Yes \\
\hline
\end{tabular}

Source: LFS 2010-2017. $n=76,024$. Notes: Standard errors in parentheses. Foreign-born respondents aged 16 and over. Personal characteristics include gender, years since migration, age on arrival, years of education (UK and foreign), whether in full-time education, ethnicity (White, Black African or Caribbean, Indian/Pakistani/Bangladeshi, Other), and year of survey. Origin controls are 132 individual countries covering $98 \%$ of the sample, and 4 dummies covering international regions (EU, Africa, Asia, Elsewhere) for the rest

$*$ denotes significance at $5 \%, * *$ at $1 \%$ and $* * *$ at $0.1 \%$ 
since migration are presented in Column 4, and Column 5 repeats this preferred specification with standard errors clustered at the origin country level, on the grounds that important shocks to identity may occur in origin-country communities.

The results in Column 1 simply reflect the raw differences apparent in Table 1. Student immigrants are around 24\% (6 percentage points) more likely to report a British national identity than economic immigrants, while family immigrants are 148\% (37 percentage points) more likely to do so, and refugees are 108\% (27 percentage points) more likely to do so. Column 2 shows that a large part of the difference between these groups and economic immigrants is attributable to demographic and human capital characteristics, with the estimates being reduced to 8,25 , and $29 \%(3,10$, and 11 percentage points) for student, family, and refugee immigrants respectively.

Student immigrants are indistinguishable from economic immigrants in their propensity to report a British identity after controlling for origin in Column 3, while both family and refugee immigrants remain more likely to report a British national identity after controlling for origin and interacting origin with years since migration. My preferred specification in Column 4 suggests that family immigrants and refugees are 13 and $8 \%$ (5 and 3 percentage points) more likely to report a British national identity than economic immigrants respectively. The precision of these estimates falls when I cluster standard errors at the origin country-level in Column 5, but the key coefficients remain statistically significant at conventional levels.

\subsection{Heterogeneity by origin and citizenship}

The average association between each immigrant group and national identity may be driven by the distinct origin country composition of the different groups. For example, Table 1 shows that family immigrants and refugees mostly come from countries outside the EU, and from countries whose citizens require a visa to enter the UK. People in these groups therefore face stronger incentives to become legal citizens in the UK, so that they can work freely, vote, and travel abroad more easily. As I note above, some immigrants may consider this legal dimension of their relationship with the host country particularly important in choosing an identity. If taking up legal citizenship makes a person feel British, and therefore leads her to report a British national identity, then my baseline results in Table 2 could simply reflect these differences in legal incentives.

Table 3 suggests that this is not so, although identity does vary across immigrants facing different legal incentives to acquire citizenship. Results in the first two columns come from re-estimating model (1) for immigrants from EU and non-EU countries. ${ }^{11,12}$ The gap between the base probabilities (33 percentage points higher for non-EU immigrants) is much larger than the differences between any of the immigrant groups, which is consistent with the idea that legal incentives for

\footnotetext{
${ }^{11}$ Excluding the 3,052 German-born respondents from the EU equation reduces the estimate for family immigrants from 0.066 to 0.051 ( $\mathrm{SE}=0.006$ ). This may reflect the impact of German-born children of British military families stationed in Germany, who have since returned to the UK.

12 The UK referendum on membership of the European Union (the 'Brexit' vote) happened during the period covered by this sample and could potentially have acted as a shock to identity for immigrants, particularly those from the EU countries. I can find no indication that it did (see Figure 6 in the Appendix). Similarly, the 'refugee crisis' in the summer of 2015 does not seem to have affected the identity of refugees relative to other groups (see Figure 7 in the Appendix).
} 


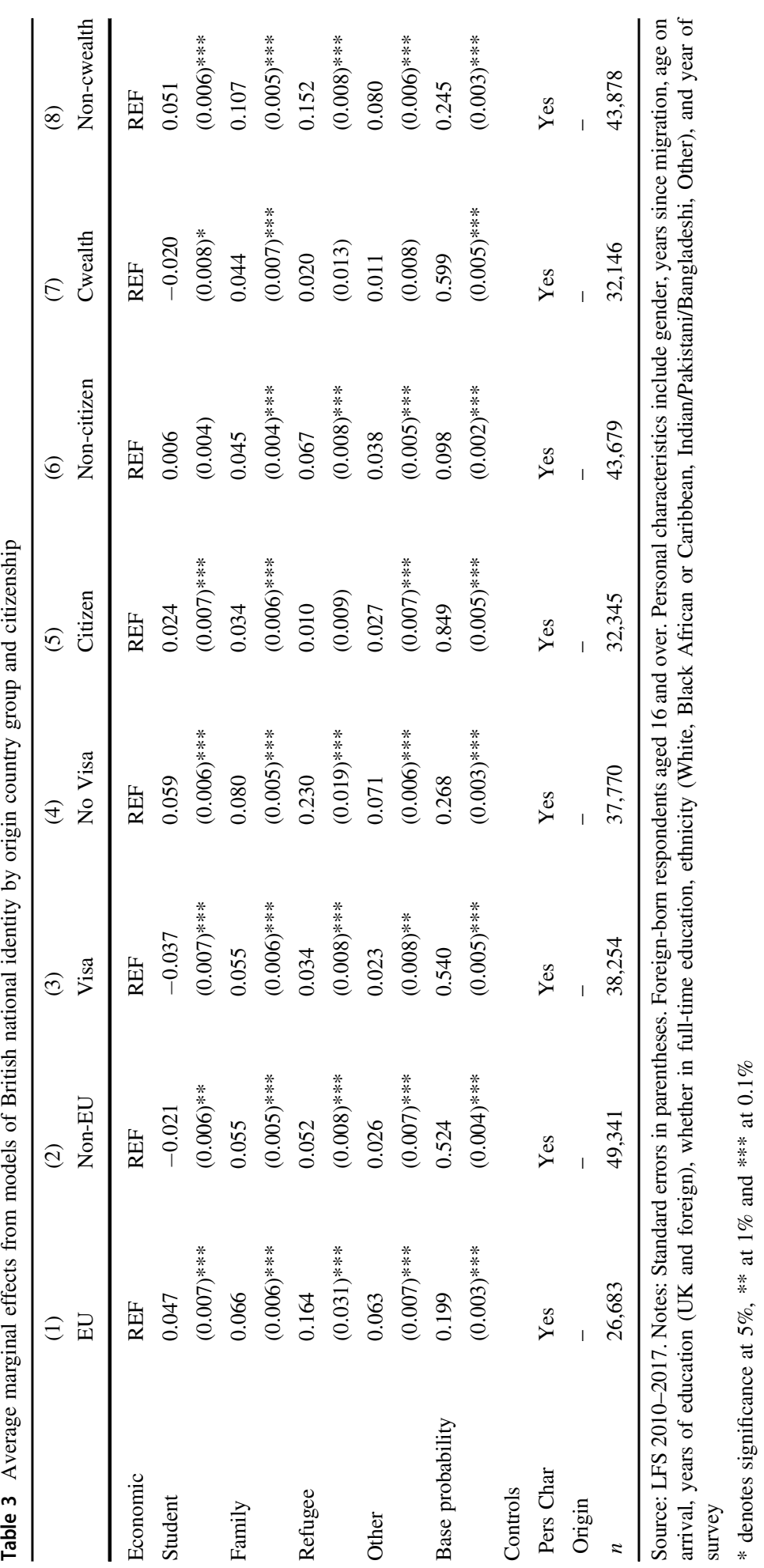


citizenship matter for identity. However, the sign of the differences between immigrant groups remains the same as in my baseline results for both EU and non-EU immigrants, with family immigrants and refugees most likely to report a British national identity in both cases. In fact, the differences between groups are larger in relative terms among those from within the EU. This may reflect the fact that economic immigrants from within the EU have particularly short average time horizons in the UK, due to the low travel and administrative costs of migration for this group, and therefore face particularly weak incentives to adopt the host citizenship or identity. Family immigrants from within the EU are 33\% (7 percentage points) more likely to report a British national identity than economic immigrants, while those from outside the EU are 10\% (6 percentage points) so. Refugees born in countries within the EU are $82 \%$ (16 percentage points) more likely to report a British national identity than economic immigrants, compared to $10 \%$ (5 percentage points) for those from outside. (This second result should be interpreted with some caution, since the number of respondents who report being born in an EU country and coming to the $\mathrm{UK}$ as a refugee is relatively small.) ${ }^{13}$

Columns 3 and 4 repeat this exercise for immigrants from countries whose citizens require a visa to enter the UK and those that do not, and the results are similar. This is perhaps not surprising, since there is a large overlap between the non-EU immigrant group and those from visa-requiring countries.

Columns 5 and 6 of Table 3 show results from re-estimating model (1) for immigrants with and without legal citizenship. The gap between the base probabilities (75 percentage points higher for citizens) is very large compared to any of the differences between immigrant groups, reflecting the high rates of British identity among those who are legal citizens. The sign of the differences between immigrant groups is again the same as in my baseline results, with family immigrants and refugees more likely to report a British national identity regardless of citizenship status, and the group differences in relative terms are larger among those without citizenship. This may be because predicted take up of the host identity is particularly low among economic immigrants without citizenship, at around $10 \%$. Among citizens, family immigrants are around $4 \%$ (3 percentage points) more likely to report a British national identity than economic immigrants, compared to $46 \%$ (5 percentage points) among non-citizens. Refugees who are citizens are only slightly more likely to report a British national identity than economic immigrants (the gap is both small and imprecisely estimated), but those who are non-citizens are $68 \%$ (7 percentage points) so.

The final two columns of Table 3 show results from re-estimating model (1) separately for immigrants from countries inside and outside of the British Commonwealth. Table 1 showed that family immigrants are much more likely than economic immigrants to be from countries inside the Commonwealth. This is potentially important since Commonwealth immigrants may feel an elevated linguistic or cultural affinity with the UK compared to others. Immigrants from these countries also have an automatic right to vote in UK elections, which could plausibly increase a feeling of

\footnotetext{
13 There are 125 respondents in the sample who report being born in an EU country but coming the UK as refugees. This is not necessarily mismeasurement: most of these respondents came to the UK before their countries of origin were in the EU. It is also possible that some of these respondents were born in the EU but sought asylum from a third country.
} 
belonging in the host polity. Indeed, the gap between the base probabilities in columns 7 and 8 (35 percentage points higher for Commonwealth immigrants) reflects the fact that immigrants from inside the Commonwealth are much more likely to report a British identity than those from outside. However, the results show that in fact the gap in British identity between economic and non-economic immigrants is larger among those from outside the Commonwealth. This may be because of the relatively low predicted take up of the host national identity among economic immigrants from outside the Commonwealth, at around 25\%. Among those from inside the Commonwealth, family immigrants are $7 \%$ (4 percentage points) more likely to report a British national identity than economic immigrants, while those from outside the Commonwealth are 44\% (11 percentage points) so. Refugees from inside the Commonwealth are only slightly more likely to report a British national identity than economic immigrants (this estimate is both small and imprecisely estimated), while those from outside the Commonwealth are $62 \%$ (15 percentage points) so.

Taken together, the results in Table 3 suggest that the higher tendency among family immigrants and refugees to report a British national identity does not simply reflect different take-up of legal citizenship, different incentives to take up legal citizenship, or home country membership of the British Commonwealth. Indeed, the group differences are largest in relative terms among those who are from outside the Commonwealth, among those who are not 'British' in the strict legal sense, and among those who face weaker legal incentives to become legally 'British'.

\section{Discussion}

I examine how national identity varies between economic, student, family, and refugee immigrants. I note that family immigrants and refugees often anticipate a longer stay in the host country than those in other immigrant groups, and that this may increase the expected gains associated with adoption of the host national identity. My results are broadly consistent with this observation. After adjusting for individual origin country and a rich set of demographic and human capital characteristics, family immigrants and refugees are $13 \%$ and $8 \%$ more likely to report the host national identity than economic immigrants respectively. This is a novel descriptive result. It does not appear to be driven only by differences in legal citizenship, by differences in incentives to acquire legal citizenship, or by home country membership of the British Commonwealth.

Time horizons may therefore be a previously neglected determinant of immigrant national identity. My analysis broadens an existing body of work that links economic dimensions of immigrant assimilation with time horizons in the host country. Dustmann (1993, 1999, 2008) shows how the educational investments and economic assimilation of immigrants are shaped by intended length of stay, and my results suggest that national identity may be considered part of a parallel assimilation process which also varies dependent on time horizons in the host country. The distinction made by Cortes (2004) between the implied time horizons of economic and refugee immigrants is also useful for understanding this identity assimilation process, and I have been able to add an additional distinction between the implied time horizons of family and student immigrants. 
More generally, if identity can vary according to an individual's intent as well as her observed characteristics at a given point in time, time horizons should perhaps be considered when addressing other aspects of identity. Pursuing this observation is beyond the scope of this paper, but, for example, it is plausible that the tendency of an individual to develop an occupational identity may depend on the length of time she expects to stay in that occupation, or that the strength of her identification with a particular local region depends on her anticipated duration of residence.

Time horizons are unobserved, and the average differences in national identity I report between immigrant groups may be driven by some alternative unobserved factor. For example, Dustmann (1996) emphasises the role of exposure to the host society in developing a host identity, and it may be that family immigrants and refugees experience more societal exposure than those from other immigrant groups on average. I show above that these groups are more likely to have children, which could increase societal exposure through engagement with institutions such as schools and hospitals. I cannot exclude the possibility that such increased exposure explains the elevated sense of British identity in these groups. However, separating the influence of time horizons and societal exposure would be difficult empirically, since such exposure could both produce and reflect longer time horizons in the host country.

Another potential explanation is that refugees are more inclined to adopt a British identity because of negative feelings about aspects of their origin society. This would be consistent with Manning and Roy's (2010) suggestion that immigrants are driven to take up the host identity when the host country compares favourably with the home country in economic and political terms, as well as with Georgiadis and Manning's (2013) observation that a feeling of tolerance and respect is important for adopting the host identity. For family immigrants, the host country seems likely to compare favourably with the origin country on a personal level, since they have by definition migrated to be among family members who will no longer be present in the home country. However, as with the role of societal exposure, longer time horizons may be driven by the fact that the host country compares favourably with the home country, or they may reflect this fact. Attempting to disentangle the underlying mechanisms is a potential avenue for future research.

Different immigrant groups are often subject to separate immigration control regimes by host countries, and it is therefore possible for governments to make policy favouring the entry or settlement of one immigrant group over another. The results I present here are descriptive, and cannot be used to inform this area of policy directly. The causal mechanisms underlying the observed relationship would need to be carefully identified before any such recommendation could be made. However, my results do suggest that host-country governments might consider dimensions of immigrant adjustment beyond the short-term economic criteria which so often dominate. Immigrants from groups that do not typically thrive economically in the short-term may turn out to be better adjusted in other respects.

Acknowledgements This work was funded by ESRC grant number 1099570. I would like to thank the Editor and two anonymous referees for their comments, and John Micklewright and Lindsey Macmillan for guidance. I also received helpful comments and suggestions from Ken Clark, Francis Green, Ana Nuevo-Chiquero, Lucinda Platt, Gurleen Popli, Anita Ratcliffe, Jon Simmons, and participants at BSPS, ESPE, RES, WPEG, and the Workshop on the Economics of Migration. Data 
are provided via the Secure Data Service. The use of these data does not imply the endorsement of the data owner or the UK Data Service at the UK Data Archive in relation to the interpretation or analysis of the data. This work uses research datasets which may not exactly reproduce National Statistics aggregates. An earlier version used data provided via Migration and Border Analysis at the Home Office. Any mistakes are mine.

\section{Compliance with ethical standards}

Conflict of interest The author declares previous research contracts at the UK Home Office, and data access at the UK Home Office relating to an earlier version of this paper.

Open Access This article is distributed under the terms of the Creative Commons Attribution 4.0 International License (http://creativecommons.org/licenses/by/4.0/), which permits use, duplication, adaptation, distribution, and reproduction in any medium or format, as long as you give appropriate credit to the original author(s) and the source, provide a link to the Creative Commons license, and indicate if changes were made.

\section{Appendix}

Tables 4-6, Figs. 4-7.

Table 4 Average marginal effects from models of 'Integrated' and 'Assimilated' vs 'Separated' national identity

\begin{tabular}{|c|c|c|c|}
\hline & Assimilated or Integrated & Assimilated & Integrated \\
\hline Economic & REF & REF & REF \\
\hline \multirow[t]{2}{*}{ Student } & 0.009 & 0.007 & 0.007 \\
\hline & $(0.005)^{*}$ & $(0.005)$ & $(0.004)$ \\
\hline \multirow[t]{2}{*}{ Family } & 0.069 & 0.067 & 0.023 \\
\hline & $(0.004)^{* * * *}$ & $(0.004)^{* * *}$ & $(0.003)^{* * * *}$ \\
\hline \multirow[t]{2}{*}{ Refugee } & 0.065 & 0.065 & 0.018 \\
\hline & $(0.006)^{* * *}$ & $(0.006)^{* * *}$ & $(0.006)^{* * *}$ \\
\hline \multirow[t]{2}{*}{ Other } & 0.047 & 0.044 & 0.014 \\
\hline & $(0.005)^{* * * *}$ & $(0.005)^{* * *}$ & $(0.004)^{* * * *}$ \\
\hline \multirow[t]{2}{*}{ Base probability } & 0.402 & 0.376 & 0.063 \\
\hline & $(0.003)^{* * * *}$ & $(0.003)^{* * *}$ & $(0.002)^{* * * *}$ \\
\hline \multicolumn{4}{|l|}{ Controls } \\
\hline Personal characteristics & Yes & Yes & Yes \\
\hline Origin & Yes & Yes & Yes \\
\hline Origin*ysm & Yes & Yes & Yes \\
\hline$n$ & 76,024 & 72,566 & 45,997 \\
\hline
\end{tabular}

Source: LFS 2010-2017. Notes: Standard errors in parentheses. Foreign born respondents aged 16 and over. Personal characteristics include gender, years since migration, age on arrival, years of education (UK and foreign), whether in full-time education, ethnicity (White, Black African or Caribbean, Indian/ Pakistani/Bangladeshi, Other), and year of survey. Origin controls are EU, Africa, Asia, and Elsewhere

$*$ denotes significance at $5 \%, * *$ at $1 \%$ and $* * *$ at $0.1 \%$

Table 4 shows results from estimating model (1) with three different outcome variables. 'Assimilated' means respondents only report a British identity, and 'Integrated' means respondents report both a British and a foreign identity. 'Assimilated or Integrated' combines these two (this is the outcome variable used in the main body of the paper). The base category in each case is 'Separated', i.e. the respondent reports only a foreign identity. Due to the smaller sample size in the 'Integrated' column, in all three columns, 'Origin' controls are EU, Africa, Asia, and Elsewhere, rather than the country fixed-effects used in the main body of the paper. 
Table 5 Average marginal effects from models of British national identity, separated by gender

\begin{tabular}{|c|c|c|c|}
\hline & $\begin{array}{l}\text { Men and } \\
\text { Women }\end{array}$ & Men & Women \\
\hline Economic & $\mathrm{REF}$ & $\mathrm{REF}$ & REF \\
\hline Student & $\begin{array}{l}0.009 \\
(0.005)^{*}\end{array}$ & $\begin{array}{l}0.015 \\
(0.007)^{*}\end{array}$ & $\begin{array}{l}0.005 \\
(0.007)\end{array}$ \\
\hline Family & $\begin{array}{l}0.069 \\
(0.004)^{* * *}\end{array}$ & $\begin{array}{l}0.086 \\
(0.006)^{* * *}\end{array}$ & $\begin{array}{l}0.065 \\
(0.006)^{* * *}\end{array}$ \\
\hline Refugee & $\begin{array}{l}0.065 \\
(0.006)^{* * *}\end{array}$ & $\begin{array}{l}0.071 \\
(0.009) * * *\end{array}$ & $\begin{array}{l}0.064 \\
(0.010)^{* * *}\end{array}$ \\
\hline Other & $\begin{array}{l}0.047 \\
(0.005)^{* * *}\end{array}$ & $\begin{array}{l}0.048 \\
(0.007)^{* * *}\end{array}$ & $\begin{array}{l}0.047 \\
(0.007)^{* * *}\end{array}$ \\
\hline Base probability & $\begin{array}{l}0.402 \\
(0.003)^{* * *}\end{array}$ & $\begin{array}{l}0.405 \\
(0.004)^{* * *}\end{array}$ & $\begin{array}{l}0.396 \\
(0.004)^{* * *}\end{array}$ \\
\hline \multicolumn{4}{|l|}{ Controls } \\
\hline $\begin{array}{l}\text { Personal } \\
\text { characteristics }\end{array}$ & Yes & Yes & Yes \\
\hline Origin & Yes & Yes & Yes \\
\hline Origin*ysm & Yes & Yes & Yes \\
\hline$n$ & 76,024 & 34,924 & 41,100 \\
\hline
\end{tabular}

Source: LFS 2010-2017. Notes: Standard errors in parentheses. Foreign born respondents aged 16 and over. Personal characteristics include gender, years since migration, age on arrival, years of education (UK and foreign), whether in full-time education, ethnicity (White, Black African or Caribbean, Indian/ Pakistani/Bangladeshi, Other), and year of survey. Origin controls are EU, Africa, Asia, and Elsewhere

$*$ denotes significance at $5 \%, * *$ at $1 \%$ and $* * *$ at $0.1 \%$

Table 5 shows results from estimating model (1) separately for men and women. Due to the smaller sample size in the 'Men' and 'Women' columns, in all three columns, 'Origin' controls are EU, Africa, Asia, and Elsewhere, rather than the country fixed-effects used in the main body of the paper 
Table 6 Average marginal effects from models of British national identity, with and without controls for employment status and pay

\begin{tabular}{|c|c|c|c|c|}
\hline & $\begin{array}{l}\text { No controls for } \\
\text { employment status }\end{array}$ & $\begin{array}{l}\text { Controls for } \\
\text { Employment status }\end{array}$ & $\begin{array}{l}\text { No controls for } \\
\text { Weekly pay }\end{array}$ & $\begin{array}{l}\text { Controls for } \\
\text { Weekly pay }\end{array}$ \\
\hline Economic & REF & REF & REF & REF \\
\hline Student & $\begin{array}{l}0.001 \\
(0.005)\end{array}$ & $\begin{array}{l}0.001 \\
(0.005)\end{array}$ & $\begin{array}{l}0.018 \\
(0.008)^{*}\end{array}$ & $\begin{array}{l}0.019 \\
(0.008)^{*}\end{array}$ \\
\hline Family & $\begin{array}{l}0.053 \\
(0.004)^{* * *}\end{array}$ & $\begin{array}{l}0.054 \\
(0.004)^{* * *}\end{array}$ & $\begin{array}{l}0.078 \\
(0.008)^{* * *}\end{array}$ & $\begin{array}{l}0.083 \\
(0.008) * * *\end{array}$ \\
\hline Refugee & $\begin{array}{l}0.031 \\
(0.007)^{* * *}\end{array}$ & $\begin{array}{l}0.031 \\
(0.007)^{* * *}\end{array}$ & $\begin{array}{l}0.080 \\
(0.013)^{* * *}\end{array}$ & $\begin{array}{l}0.089 \\
(0.014)^{* * *}\end{array}$ \\
\hline Other & $\begin{array}{l}0.033 \\
(0.005)^{* * *}\end{array}$ & $\begin{array}{l}0.033 \\
(0.005)^{* * *}\end{array}$ & $\begin{array}{l}0.037 \\
(0.009)^{* * *}\end{array}$ & $\begin{array}{l}0.041 \\
(0.010)^{* * *}\end{array}$ \\
\hline Base probability & $\begin{array}{l}0.413 \\
(0.003)^{* * *}\end{array}$ & $\begin{array}{l}0.413 \\
(0.003)^{* * *}\end{array}$ & $\begin{array}{l}0.368 \\
(0.005)^{* * *}\end{array}$ & $\begin{array}{l}0.366 \\
(0.005)^{* * *}\end{array}$ \\
\hline \multicolumn{5}{|l|}{ Controls } \\
\hline $\begin{array}{l}\text { Personal } \\
\text { characteristics }\end{array}$ & Yes & Yes & Yes & Yes \\
\hline Origin & Yes & Yes & Yes & Yes \\
\hline Origin*ysm & Yes & Yes & Yes & Yes \\
\hline $\begin{array}{l}\text { Employment } \\
\text { controls }\end{array}$ & - & Yes & - & - \\
\hline Income controls & - & - & - & Yes \\
\hline$n$ & 76,024 & 76,024 & 20,923 & 20,923 \\
\hline
\end{tabular}

Source: LFS 2010-2017. Notes: Standard errors in parentheses. * denotes significance at 5\%,** at $1 \%$ and *** at $0.1 \%$. Foreign born respondents aged 16 and over. Personal characteristics include gender, years since migration, age on arrival, years of education (UK and foreign), whether in full-time education, ethnicity (White, Black African or Caribbean, Indian/Pakistani/Bangladeshi, Other), and year of survey. Origin controls in the two 'Employment status' columns are 132 individual countries covering $98 \%$ of the sample, and 4 dummies covering international regions (EU, Africa, Asia, Elsewhere) for the rest. Origin controls in the two 'Weekly pay' columns are EU, Africa, Asia, and Elsewhere. Employment controls are 'Employed', 'Unemployed', and 'Inactive'. Income controls are 'Gross weekly pay in main job' and its square (due to the design of the LFS, this information is only available on around $45 \%$ of the employed sample)

Table 6 shows results from estimating model (1) with and without controls for employment status and weekly income. Due to the smaller sample size, in the two 'Weekly pay' columns 'Origin' controls are EU, Africa, Asia, and Elsewhere, rather than the country fixed-effects used in the two 'Employment status' columns and in the main body of the paper 


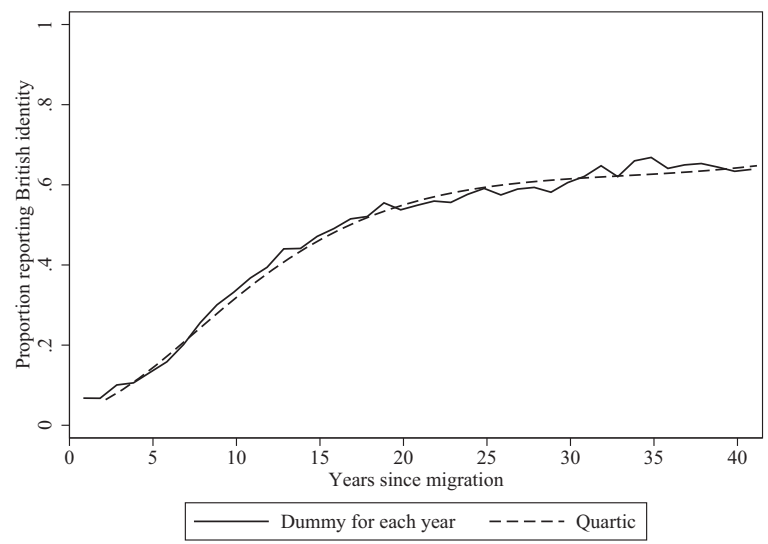

Fig. 4 British national identity over years since migration represented as multiple dummy variables versus a quartic. Source, LFS, 2010-2017. $n=76,024$. This figure plots predicted probabilities of British national identity over years since migration, estimated with (1) a model controlling for immigrant group, personal characteristics, origin, and a dummy for each year since migration and (2) the same model with a quartic in years since migration instead of a dummy for each year. Personal characteristics include gender, age on arrival, years of education (UK and foreign), whether in full-time education, ethnicity (White, Black African or Caribbean, Indian/Pakistani/Bangladeshi, Other), and year of survey. Origin controls are 132 individual countries covering $98 \%$ of the sample, and 4 dummies covering international regions (EU, Africa, Asia, Elsewhere) for the rest

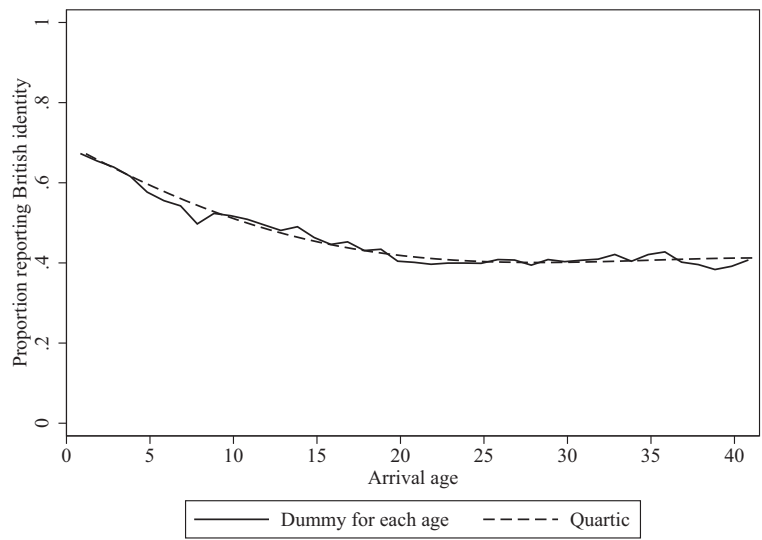

Fig. 5 British national identity over age on arrival represented as multiple dummy variables versus a quartic. Source, LFS, 2010-2017. $n=76,024$. This figure plots predicted probabilities of British national identity over arrival age, estimated with (1) a model controlling for immigrant group, personal characteristics, origin, and a dummy for each arrival age and (2) the same model with a quartic in arrival age instead of a dummy for each age. Personal characteristics include gender, years since migration, years of education (UK and foreign), whether in full-time education, ethnicity (White, Black African or Caribbean, Indian/Pakistani/Bangladeshi, Other), and year of survey. Origin controls are 132 individual countries covering $98 \%$ of the sample, and 4 dummies covering international regions (EU, Africa, Asia, Elsewhere) for the rest 


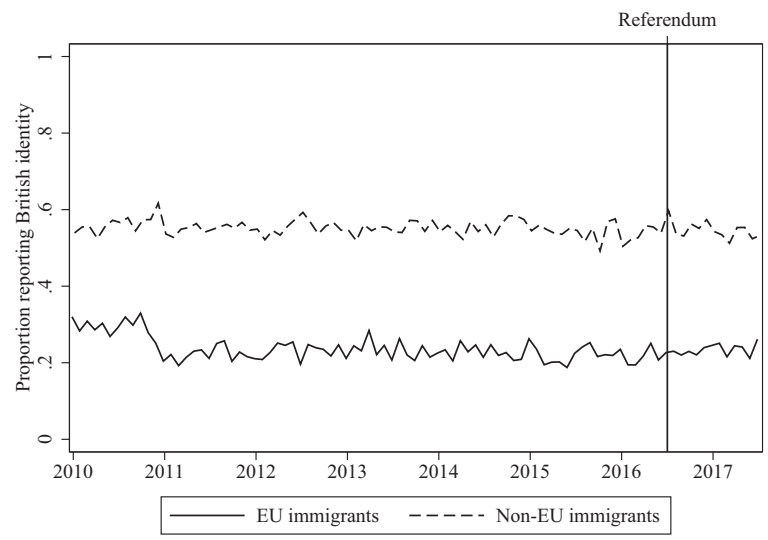

Fig. 6 British national identity for EU and non-EU immigrants, before and after "Brexit" referendum in June 2016. Source, LFS, 2010-2017. $n=76,024$. This figure plots predicted probabilities of British national identity over month of survey, estimated separately for EU and non-EU immigrants. Each model controls for immigrant group and personal characteristics. Personal characteristics include gender, years since migration, age on arrival, years of education (UK and foreign), whether in full-time education, ethnicity (White, Black African or Caribbean, Indian/Pakistani/Bangladeshi, Other), and year of survey

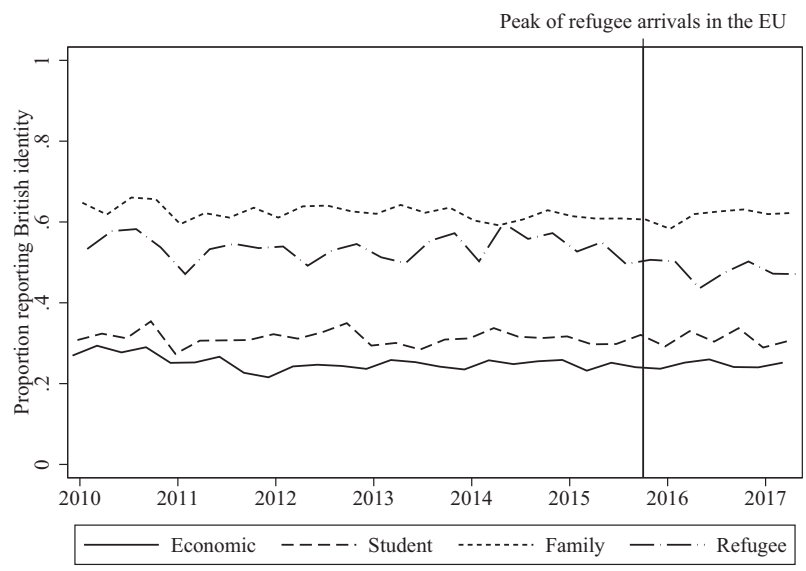

Fig. 7 British national identity by immigrant group, before and after peak of refugee arrivals in the EU. Source, LFS, 2010-2017. $n=76,024$. This figure plots predicted probabilities of British national identity over each calendar quarter, estimated separately for economic, student, family, and refugee immigrants. Each model controls for international region of origin and personal characteristics. Origin controls are EU, Africa, Asia, and Elsewhere. Personal characteristics include gender, years since migration, age on arrival, years of education (UK and foreign), whether in full-time education, ethnicity (White, Black African or Caribbean, Indian/Pakistani/Bangladeshi, Other), and year of survey. "Peak of refugee arrivals in the EU" is October-December 2015 (Eurostat 2018)

\section{References}

Adda, J., C. Dustmann, and J.-S. Görlach (2015). The dynamics of return migration, human capital accumulation, and wage assimilation. Unpublished.

Akerlof, G. A. (1997). Social distance and social decisions. Econometrica, 65(5), 1005-1028. 
Akerlof, G. A., \& Kranton, R. E. (2000). Economics and identity. The Quarterly Journal of Economics, 115(3), 715-753.

Akerlof, G. A., \& Kranton, R. E. (2002). Identity and schooling: some lessons for the economics of education. Journal of Economic Literature, 40(4), 1167-1201.

Akerlof, G. A., \& Kranton, R. E. (2005). Identity and the economics of organizations. Journal of Economic Perspectives, 19(1), 9-32.

Aydemir, A. (2011). Immigrant selection and short-term labor market outcomes by visa category. Journal of Population Economics, 24(2), 451-475.

Battu, H., Mwale, M., \& Zenou, Y. (2007). Oppositional identities and the labor market. Journal of Population Economics, 20(3), 643-667.

Battu, H., \& Zenou, Y. (2010). Oppositional identities and employment for ethnic minorities: evidence from England. The Economic Journal, 120(542), F52-F71.

Bénabou, R., \& Tirole, J. (2011). Identity, morals, and taboos: beliefs as assets. The Quarterly Journal of Economics, 126(2), 805-855.

Bell, B., Fasani, F., \& Machin, S. (2013). Crime and immigration: evidence from large immigrant waves. Review of Economics and Statistics, 21(3), 1278-1290.

Bernhard, H., Fehr, E., \& Fischbacher, U. (2006). Group affiliation and altruistic norm enforcement. The American Economic Review, 96(2), 217-221.

Berry, J. W. (1974). Psychological aspects of cultural pluralism: unity and identity reconsidered. Topics in Culture Learning, 2, 17-22.

Berry, J. W. (1997). Immigration, acculturation and adaptation. Applied Psychology: An International Review, 46, 5-68.

Bevelander, P., \& Pendakur, R. (2014). The labour market integration of refugee and family reunion immigrants: a comparison of outcomes in Canada and Sweden. Journal of Ethnic and Migration Studies, 40(5), 689-709.

Bijwaard, G. E. (2010). Immigrant migration dynamics model for the Netherlands. Journal of Population Economics, 23(4), 1213-1247.

Bisin, A., Patacchini, E., Verdier, T., \& Zenou, Y. (2011a). Ethnic identity and labour market outcomes of immigrants in Europe. Economic Policy, 26(65), 57-92.

Bisin, A., Patacchini, E., Verdier, T., \& Zenou, Y. (2011b). Formation and persistence of oppositional identities. European Economic Review, 55(8), 1046-1071.

Bisin, A., Patacchini, E., Verdier, T., \& Zenou, Y. (2016). Bend it like Beckham: ethnic identity and integration. European Economic Review, 90, 146-64.

Bloch, A. (2008). Refugees in the UK labour market: the conflict between economic integration and policy-led labour market restriction. Journal of Social Policy, 37(1), 21-36.

Borjas, G. J. (1982). The labor supply of male Hispanic immigrants in the United States. Industrial and Labor Relations Review, 35(3), 343-353.

Bratsberg, B. (1995). The incidence of non-return among foreign students in the United States. Economics of Education Review, 14(4), 373-384.

Casey, T., \& Dustmann, C. (2010). Immigrants' identity, economic outcomes and the transmission of identity across generations. The Economic Journal, 120(542), F31-F51.

Chen, Y., \& Li, S. X. (2009). Group identity and social preferences. The American Economic Review, 99 (1), 431-457.

Cobb-Clark, D. A. (2006). Selection policy and the labour market outcomes of new immigrants. In: D. A. Cobb-Clark \& S. Khoo (Eds.), Public policy and immigrant settlement. Cheltenham: Edward Elgar.

Constant, A. F., Gataullina, L., \& Zimmermann, K.F. (2006). Gender, ethnic identity and work. IZA Discussion Paper, 2420.

Constant, A. F., Gataullina, L., \& Zimmermann, K. F. (2009). Ethnosizing immigrants. Journal of Economic Behavior and Organization, 69(3), 274-287.

Constant, A. F., \& Zimmermann, K. F. (2008). Measuring ethnic identity and its impact on economic behavior. Journal of the European Economic Association, 6(2-3), 424-433.

Cortes, K. E. (2004). Are refugees different from economic immigrants? Some empirical evidence on the heterogeneity of immigrant groups in the United States. Review of Economics and Statistics, 86(2), $465-480$.

Costa i Font, J., \& Cowell, F. (2015). Social identity and redistributive preferences: a survey. Journal of Economic Surveys, 29(2), 357-374.

Depetris-Chauvin, E., Durante, R,. \& Campante, F.R. (2018). Building nations through shared experiences: evidence from African Football. NBER WP 24666. 
DeVoretz, D. J., Beiser, M., \& Pivnenko, S. (2005). The economic experiences of refugees in Canada. In P. Waxman \& V. Colic-Peisker (Eds.), Homeland wanted: interdisciplinary perspectives on refugee settlement in the West. New York: Nova Science.

Drydakis, N. (2013). The effect of ethnic identity on the employment of immigrants. Review of Economics of the Household, 11(2), 285-308.

Duke, K. (1996). The resettlement experiences of refugees in the UK: Main findings from an interview study. Journal of Ethnic and Migration Studies, 22(3), 461-478.

Dustmann, C. (1993). Earnings adjustment of temporary migrants. Journal of Population Economics, 6(2), 153-68.

Dustmann, C. (1996). The social assimilation of immigrants. Journal of Population Economics, 9(1), 37-54.

Dustmann, C. (1999). Temporary migration, human capital, and language fluency of migrants. The Scandinavian Journal of Economics, 101(2), 297-314.

Dustmann, C. (2008). Return migration, investment in children, and intergenerational mobility: comparing sons of foreign-and native-born fathers. Journal of Human Resources, 43(2), 299-324.

Dustmann, C., \& Görlach, J.-S. (2016). The economics of temporary migrations. Journal of Economic Literature, 54(1), 98-136.

Eurostat (2018). Asylum and managed migration. Luxembourg: European Commission.

Ferrie, J. P., \& Hatton, T. J. (2015). Two centuries of international migration. In: Chiswick, B.R. \& Miller, P.W, (Eds.), Handbook of the Economics of International Migration (Vol. 1, pp. 53-88). Oxford: North-Holland.

Georgiadis, A., \& Manning, A. (2013). One nation under a groove? Understanding national identity. Journal of Economic Behavior and Organization, 93, 166-185.

Heath, A. F., \& Tilley, J. R. (2005). British national identity and attitudes towards immigration. International Journal on Multicultural Societies, 7(2), 119-132.

Home Office. (2014). Migrant journey: Fourth Report. London: Home Office.

Home Office. (2018a). Becoming a British citizen. London: Home Office.

Home Office. (2018b). Immigration statistics, year ending March 2018. London: Home Office..

Islam, A., \& Raschky, P. A. (2015). Genetic distance, immigrants' identity, and labor market outcomes. Journal of Population Economics, 28(3), 845-868.

Kellner, P. (2007). What Britishness means to the British. The Political Quarterly, 78(S1), 62-71.

Khan, A. H. (1997). Post-migration investment in education by immigrants in the United States. The Quarterly Review of Economics and Finance, 37, 285-313.

Kiss, Z., \& Park, A. (2014). National Identity: exploring Britishness. In: Park, A., Bryson, C., \& Curtice,J. (Eds.), British social attitudes: the 31st Report. London: NatCen Social Research.

Kranton, R. E. (2016). Identity economics 2016: Where do social distinctions and norms come from? American Economic Review: Papers and Proceedings 106(5), 405-09.

Manning, A., \& Roy, S. (2010). Culture clash or culture club? National identity in Britain. The Economic Journal, 120(542), F72-F100.

Masella, P. (2013). National identity and ethnic diversity. Journal of Population Economics, 26(2), 437-454.

Mason, P. L. (2004). Annual income, hourly wages, and identity among Mexican-Americans and other Latinos. Industrial Relations: A Journal of Economy and Society, 43(4), 817-834.

Merton, R. K. (1968). Social theory and social structure. New York, NY: Free Press.

Nandi, A., \& Platt, L. (2015). Patterns of minority and majority identification in a multicultural society. Ethnic and Racial Studies, 38(15), 2615-2634.

Nekby, L., \& Rödin, M. (2010). Acculturation identity and employment among second and middle generation immigrants. Journal of Economic Psychology, 31(1), 35-50.

Nekby, L., Rödin, M., \& Özcan, G. (2009). Acculturation identity and higher education: Is there a trade-off between ethnic identity and education? International Migration Review, 43(4), 938-973.

Office for National Statistics. (2007). Estimating international migration: an exploration of the definitional differences between the Labour Force Survey, Annual Population Survey, International Passenger Survey and Long-Term International Migration. London: ONS.

Office for National Statistics (2018). Quarterly Labour Force Survey, 1992-2017: secure access (12th edn.). UK Data Service. SN: 6727.

Pendakur, K., \& Pendakur, R. (2005). Ethnic identity and the labour market. Unpublished.

Platt, L. (2014). Is there assimilation in minority groups' national, ethnic and religious identity? Ethnic and Racial Studies, 37(1), 46-70. 
Ruiz, I., \& Vargas-Silva, C. (2018). Differences in labour market outcomes between natives, refugees and other migrants in the UK. Journal of Economic Geography, 18(4), 855-885.

Schüller, S. (2015). Parental ethnic identity and educational attainment of second-generation immigrants. Journal of Population Economics, 28(4), 965-1004.

Tajfel, H., \& Turner, J. C. (1979). An integrative theory of intergroup conflict. The Social Psychology of Intergroup Relations, 33(47), 74.

Uberoi, V., \& McLean, I. (2007). Britishness: a role for the state? The Political Quarterly, 78(S1), 41-53.

Wetherell, M. (1996). Group conflict and the social psychology of racism. In M. Wetherell (Ed.), Identities, groups, and social issues. London: Sage. 